\title{
Mechanisms for Managing Complaints in Kajen Hospital, Pekalongan Regency
}

\author{
Herbasuki Nurcahyanto \\ \{herbasukinurcahyanto@lecturer.undip.ac.id\} \\ Universitas Diponegoro, Indonesia
}

\begin{abstract}
Patient complaints are an indicator of the public services, which have not met community satisfaction. This study conducted at Kajen Hospital in Pekalongan district aims at analyzing the management of patient complaints and identifying various obstacles. The study uses qualitative methods. The results show that patient complaints can be made in various ways, namely through SMS call center, Kajen regional hospital web, Kajen regional hospital WhatsApp and in the conventional way using letters. The speed of response in handling complaints is above the standards set by SNARS. This complaint handling uses the Plan Do Study Action (PDSA) approach. Obstacles that can be identified are, among others, limited number of professional staff and a specific room for complaints. In order to improve further performance, a variety of professional support facilities and resources are needed to overcome increasingly complex challenges in the future.
\end{abstract}

Keywords: Management of Patient Complaints.

\section{Introduction}

The implementation of public services is a state effort to fulfill the basic needs and civil rights of every citizen. The 1945 Constitution mandated the State to fulfill the necessity of every citizen in order to achieve prosperity. In order to fulfill the basic needs of the citizens, the Government must be able to conduct excellent public services in a fair way and without discrimination.

Health service is an important basic service in society. Hospitals are required to be able to provide the best service for every user of the hospital. When found dissatisfaction in the service, the user can express a complaint. The mechanism of public complaints in some government agencies is in the form of suggestion boxes and short messages through SMS that are not integrated in an effective and transparent mechanism. The absence of information about the procedure of delivery and settlement of complaints, and officers' responsibility makes the community less capable of supervising the complaints handling process. The category and number of complaints service at Kajen Hospital can be seen in Table 1.

Table 1. Category of Service Complaints of Kajen Hospital from January to June 2019

\begin{tabular}{|c|l|c|}
\hline No & \multicolumn{1}{|c|}{ Complaint Categories } & Amount \\
\hline 1 & Facility and Infrastructure & 13 \\
\hline 2 & Administration & 17 \\
\hline 3 & Nursery & 14 \\
\hline 4 & Medical & 11 \\
\hline
\end{tabular}




\begin{tabular}{|l|l|c|}
\hline & Total & 55 \\
\hline \multicolumn{3}{|c|}{ Source: Kajen Hospital, 2019.}
\end{tabular}

The number of complaints indicates problems in providing services to the patient. The research aims to analyze management of complaints and identify various obstacles in the management of complaints at Kajen Hospital.

\section{Research Method}

This research is located at Kajen Hospital of Pekalongan District, using qualitative research method with case Study approach as follows 1). The technique of selecting the informant used by the authors in this study is to set the key informants, who are trusted persons and service users who commit complaints. The data collection techniques used by researchers are interviews, observations and documentation. The type of data used by researchers is primary data and secondary data. The analysis of the data uses an exploratory descriptive analysis technique [1].

\section{Result and Discussion}

Barlow and Møller [2] said a complaint includes 'statements about expectations that have not been met'. Complaints procedures have been promoted in public services since the 1990 s as a means to increase user participation, to increase 'satisfaction' with services and to provide a feedback mechanism for managers on the problem areas. Community complaint is a part of response of service dissatisfaction from community conveyed both directly and indirectly about service given by the provider.

Managing complaint starts from the complaint entry process up to how the complaint is completed, and it also concerns how the control mechanisms to obtain good results. In principle, complaint service to the provider is sought to facilitate users who will deliver complaints. Complaints can be done, among others, by providing hotline, fax and website services. The Queensland Ombudsman mentions that the complaint is "expression of dissatisfaction made to or about an organization, related to its products, services, staff or the handling of a complaint, where a response or resolution is explicitly or implicitly expected or legally required". Kernaghan [3] mentioned that "complaints management encompasses techniques, processes and systems that lessen the chance of consumers having problems and allow businesses to respond fairly, efficiently and effectively when complaints arise". Based on the definition, the complaint management can be interpreted as a system for the acceptance of complaints, complaints recording, processing of complaints, answering complaints and complaint handling for problem solving. Handling complaint is based on certain principles that are closely related to public service principles. These principles are as follows:

1 Service Standardization

2 Complaint Definitions

3 Relevancy
4 Agreement between organizer and user

5 Oriented to the user

6 Anonymous

7 Transparency 
The Regulation of Ministry of Administrative and Bureaucratic Reform Number 24 in 2014 [4] on the guidelines of Implementation of public service complaint management nationally mentions that to ensure the improvement of public service quality is continuous and ongoing management requires Management of complaints [5]. There are two aspects of the complaint, namely: first, the interest aspects of the organizer (service providers) and second, the importance of the recipient's service (customers). This Aspect of the organizers, interests, complaint management is meaning to improve the quality of public service organizers. In contrast, the beneficiaries ' aspect of service and society is a means of conveying complaints to obtain better service. Further in Regulation of Ministry of Administrative and Bureaucratic Reform Number 24 in 2014 mentioned that the complaint is the submission of the complaint submitted by the complainant to the manager [4]. Public service complaints are on the Executive service that is not in accordance with the service standards or the waiver Obligations and/or violations of a ban by the organizer.

Along with the progress of information and technology then the government issued The Regulation of Ministry of Administrative and Bureaucratic Reform No 62 in 2018 [6]. It is about the guidelines of the National Public Service complaint management system as mentioned that the National Public Service Complaints Management System (SP4N) is an integrated management of complaints in stratified levels of each organizer in line with the framework of public service information system. Further, The Regulation of Ministry of Administrative and Bureaucratic Reform says application of National public service complaint management system uses LAPOR application which is also called SP4N-LAPOR! It is a kind of online complaint delivery service of all people's aspirations and complaints integrated in the management of complaints on every public service organizer and managed by the Ministry of State Administrative and Bureaucratic Reform in collaboration with the Office of Staff president and Ombudsman [7].

Kajen Hospital establishes the management of complaints handling in order to resolve complaints related to services directly or indirectly. Complaint Media can be submitted via: SMS Call Center, Web, Kajen Hospital application and by conventional way of using mail. The complaint is directly conveyed by using telephone and direct communication. Complaints can be categorized as follows: General complaint and service complaint. Complaint submission can be conveyed by patient, patient family, guest/visitors and officers. Indirect complaint handling procedure is as follows:

a) Receiving complaint report via either SMS Call Center or written letter.

b) Carrying out clarification and grouping types of received complaints based on clear criteria, including infrastructure services, administrative services, nursing services, and medical services.

c) Giving response or explanation that can be conveyed via SMS directly to complaint sender.

d) Involving the unit/part or staff/individual referred to the internal clarification on the problems that have occurred based on the chronological events.

e) Ensuring the problem and finding the best way out of both sides, if problems are solved then feedback to the reporting party.

f) If the problem is not solved then looking for solutions and solving common problems involving related fields, and when a policy is required it can involve follow-up to the PPIP team (Public Information Management office).

The procedure for submitting a complaint can be done by as follows: 1) through the information presented directly in the general approval form by the staff of TPPRI (Inpatient Registration Site/Place For The Patient Registration) and the groove installed in the Every 
room. 2) using the means of communication in writing or SMS Call Center or letter, 3) directly or indirectly handled immediately with the unit authorized in the face of complaints and immediately provide the patient's expected solution and 4) complaints Immediately followed up by knowing the problems and finding the best solution for both patients and hospitals. The complaint handling is not directly done by the following procedure (Fig. 1).

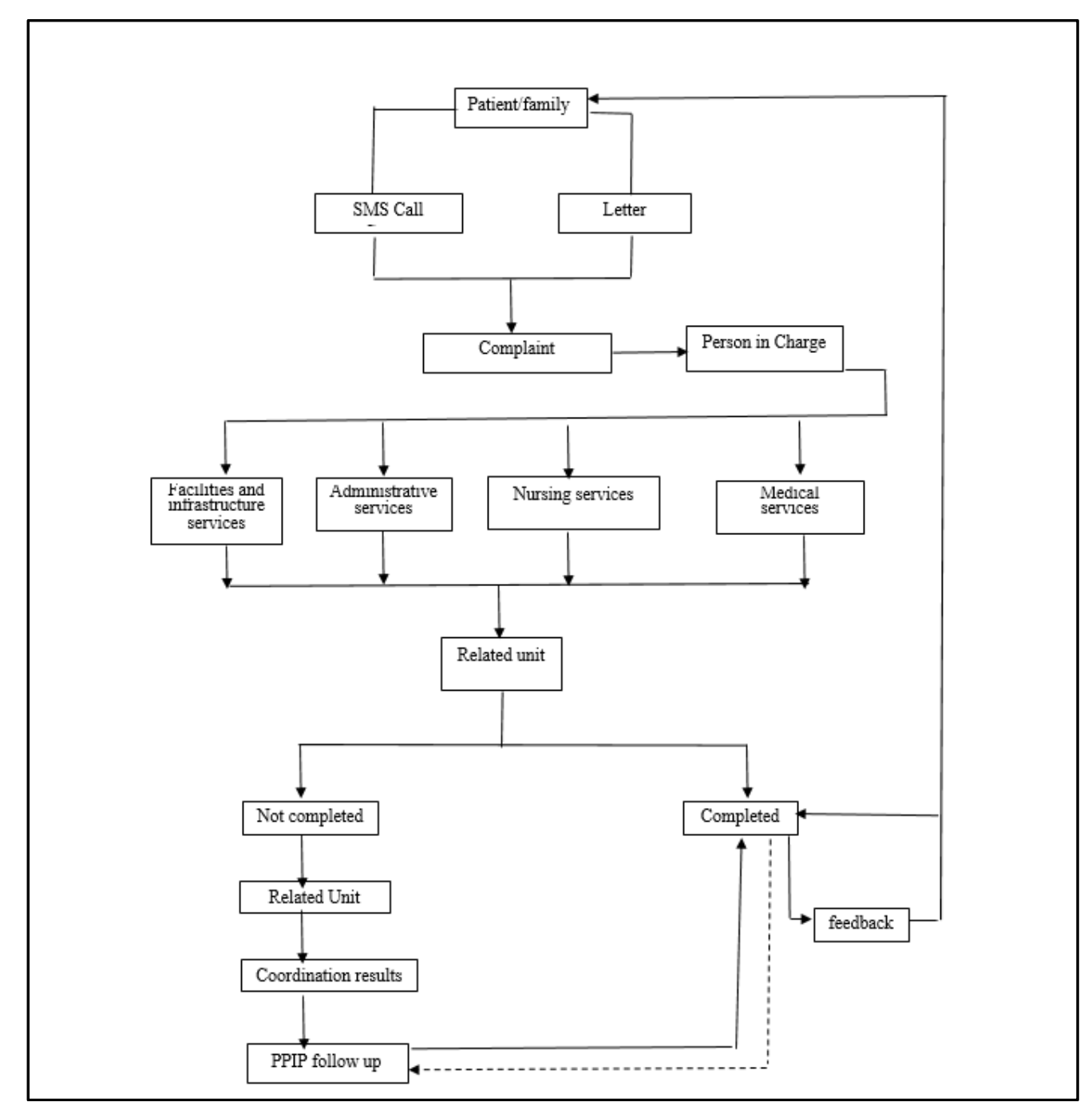

Fig. 1. Flow Indirect Complaints Handling Source: Kajen Hospital, 2019. 
Direct complaint handling is solved with the following procedure (Fig: 2).

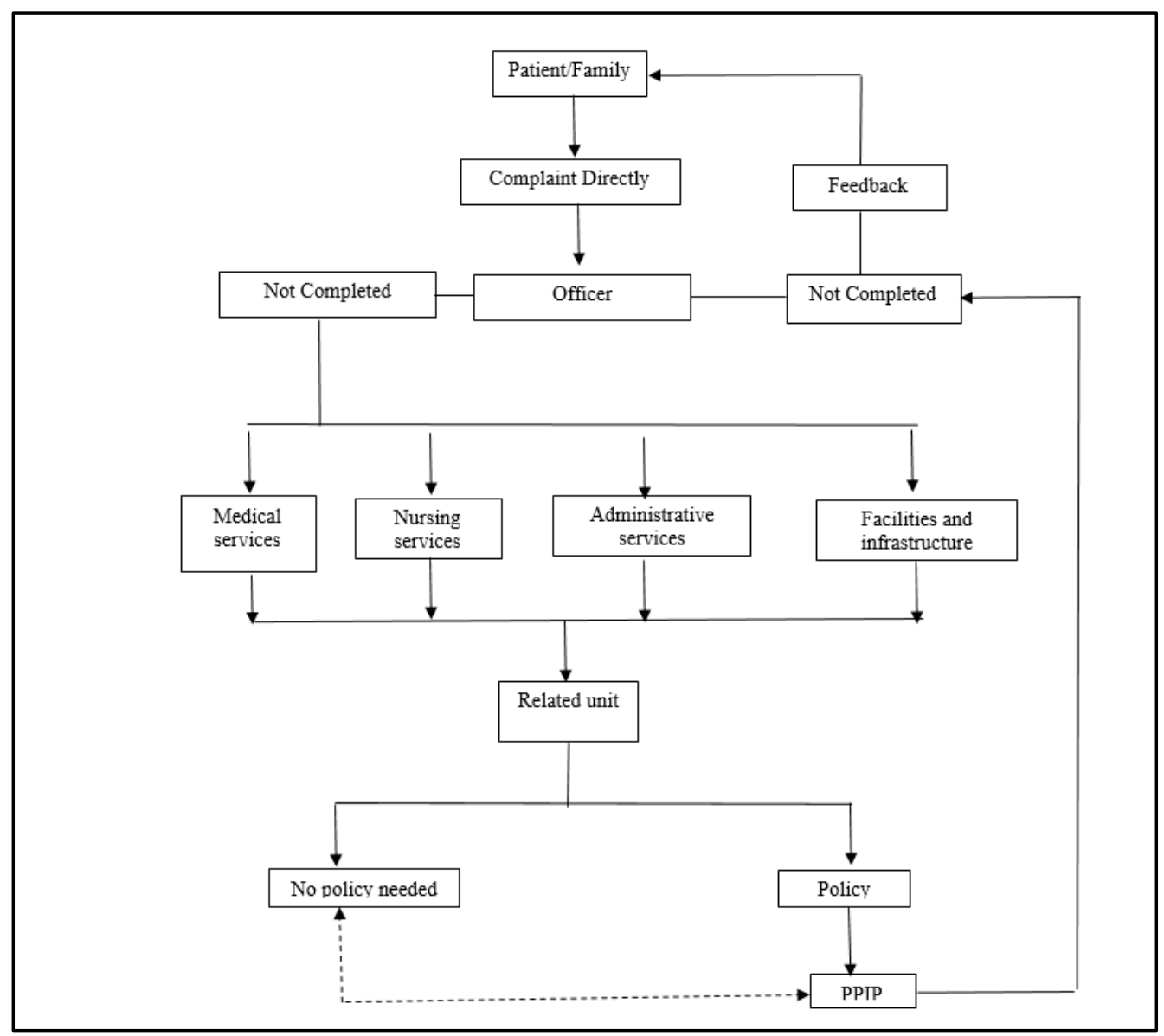

Fig. 2. Flow Direct Complaints Handling Source: Kajen Hospital, 2019.

Direct complaint handling procedure classifying as follows:

a) Invite patients who deliver complaints to a quieter and more conducive room/place.

b) Provide balanced responses/confirmations; keep an eye on the ethics of communicating with reporters.

c) Ensure patient satisfaction in obtaining solutions or alternative problem solving that they face, if the problem is solved, give feedback to the reporting party.

d) If the problem is not complete then look for solutions and solving common problems involving related fields, when a policy is required. it can involve follow-up to the PPIP team (Public Information Management office).

e) Record all patient complaints or grievances and convey complaints to related field and give response for solutions when they are in authority.

The procedure of reporting in Kajen Hospital of Pekalongan District as follows: 
a) Any complaint that has been conveyed directly or indirectly by the patient is recorded in the complaints.

b) Recording starts based on the date and time of receipt of complaint, patient name, and medical record number, incident description, unit, and staff complained, solution provided.

c) For complaints conveyed by other parties (not patient), write the person's name without a medical record number.

d) Complaints involving leaders in making decisions are immediately reported immediately during the workdays, if it is outside working hours, and then it can be through the person in charge of the time.

e) All incoming complaints through reporting System (SMS Call Center) are listed, signed by the person responsible in resolving the complaint at the hospital that is public information Officer (PPIP).

f) Public Information Officer (PPIP) will provide a report in writing to the director of the hospital monthly and it is evaluating once in every six months.

g) The report is accompanied by a series and summary of the solutions that have been given, along with proof of attachment of existing events.

h) Solutions to the problems requiring the director's decision as a final decision are promptly delivered and followed up to the patient as a step of giving solution.

The fast response to complaints can be identified based on the level of risk in the form of extreme (red), high (yellow), Low (green), and evidenced by the data and follow up on the complaint timeline response with categorization/grading/ Impact/risk.

a) Red color (KKM): tends to relate to police, court, and pass away, threatening system/sustainability of the Organization. Potential loss of material, responded, and acted upon maximum 24 hours.

b) Yellow Color (KKK): tends to relate to media coverage. It is potential loss of immaterial and responded to and acted out maximum of 3 days.

c) Green color $(\mathrm{KKH})$ : does not because loss means both material and immaterial, responded, and acted out a maximum of 7 days.

Complaints handling in Kajen Hospital use the Plan Do Study Action (PDSA) approach as follows:

a) Plan: Immediate response to complaints of more than $75 \%$.

b) Do: Red Category Complaint (KKM) is responded to and acted out maximum 1 day; the Yellow Category Complaint (KKK) is responded and acted out maximum 3 days; Green Category Complaint (KKH) is responded to and acted out a maximum of 7 days.

c) Study

- Structure: SPO, HR, facility.

- Process: Every complaint is carried out by a procedure in accordance with the flow of complaint and most complaints about administrative services of BPJS.

- Outcome: Speed of response to complaint as per standard.

d) Action: Socialization of the procedure and administrative requirements of BPJS patient services; monitoring or supervision by PPIP team.

In order to implement Regulation of Ministry of Administrative and Bureaucratic Reform Number 62 in 2018 [6], at this time, Kajen Hospital has not been able to integrate into the National Public Service complaint management system using the REPORT application! which is also called -REPORT! Based on the results of observations on the field some barriers found about the handling of complaints management in Kajen Hospital such as the existence of public reluctance to use public complain facilities, the absence of information on the 
complaint mechanism to Community, the absence of a special complaint space regarding complaints. The problem of inhibiting complaints problems in Kajen Hospital, among others:

a) Human Resources

The lack number of professional professionals dealing with complaints so that the complaints unit in Kajen Hospital is not maximum. Service users feel confused where to report an existing complaint.

b) Facility

There has been no special room in Kajen Hospital that serves as a complaint service room so that people are confused where to report a complaint, make complaint or give suggestion.

\section{Conclusion}

This research shows that service complaints in Kajen Hospital can be done directly or indirectly through various ways, either by using information technology or by mail as seen in Fig. 3. Complaint management is solved by the PDSA approach. A few things still require improvement. Thus, Kajen Hospital of Pekalongan District is expected to continuously improve the service together with a variety of facilities and resources support to overcome the challenges ahead that increasingly complex to create a satisfaction for the service users. Based on Barlow and Møllerand Kernaghan's theory, Kajen Hospital has applied complaint procedure with the following result.

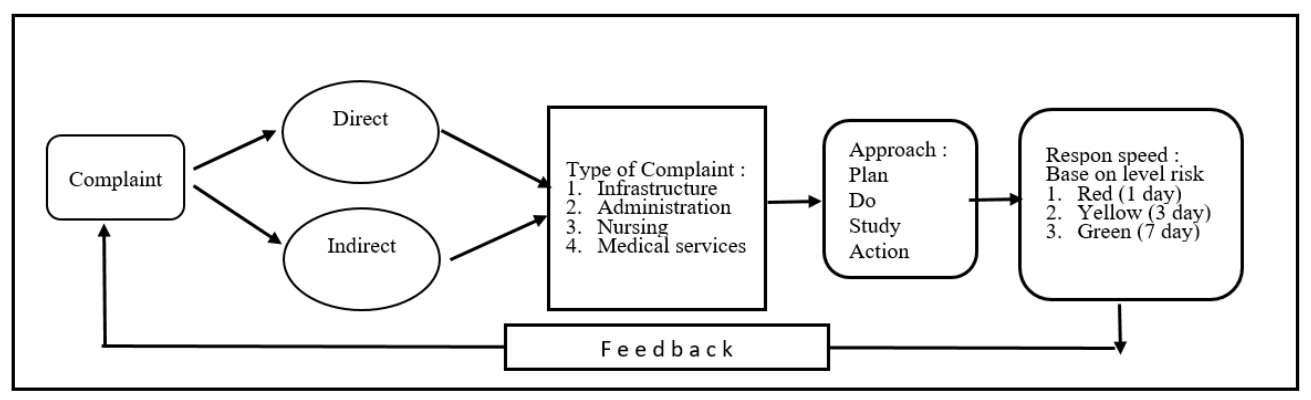

Fig. 3. Complaint Management Mechanism

Source: The researcher's analysis on Complaint Management Mechanism, 2019.

\section{References}

[1] J. W. Creswell, Research Design Pendekatan Kualitatif, Kuantitatif, dan Mixed, Edisi Ketiga. Bandung: Pustaka Pelajar, 2008.

[2] J. Barlow and C. Møller, A complaint is a gift: Using customer feedback as a strategic tool. Berrett-koehler publishers, 1996.

[3] K. Kernaghan, "The post-bureaucratic organization and public service values," Int. Rev. Adm. Sci., 2000

[4] "Peraturan Menteri Pendayagunaan Aparatur Negara dan Reformasi Birokrasi no 24 tahun 2014 tentang Pedoman Penyelenggaraan Pengelolaan Pengaduan Pelayanan Publik Secara Nasional.” 
[5] J. Gulland, "Taking complaints seriously: the role of informality in complaints about public services," Soc. Policy Soc., vol. 10, no. 4, pp. 483-493, 2011.

[6] "Peraturan Menteri Pendayagunaan Aparatur Negara dan Reformasi Birokrasi nomor 62 tahun 2018 tentang Pedoman Sistem Pengelolaan Pengaduan Pelayanan Publik Nasional.”.

[7] N. A. Daim, Hukum administrasi: perbandingan penyelesaian maladministrasi oleh Ombudsman dan pengadilan tata usaha negara. Laksbang Justitia, 2014. 